Research article

\title{
Morphological and molecular characterization of Colletotrichum capsici causing leaf-spot of soybean
}

\begin{abstract}
Rajyasri Ghosh $^{1}$, Sreetama Bhadra ${ }^{2}$ and Maumita Bandyopadhyay ${ }^{2}$
${ }^{1}$ Department of Botany, Scottish Church College, 1 \& 3 Urquhart Square, Kolkata, West Bengal, India ${ }^{2}$ Department of Botany, University of Calcutta, 35 Ballygunge Circular Road, Kolkata, West Bengal, India *Corresponding Author: rajyasri_5@rediffmail.com

[Accepted: 14 September 2016]

Abstract: In the present investigation an attempt was made to carry out morphological and molecular characterization of Colletotrichum isolate (CI) associated with leaf spot disease of soybean. Pathogenicity test was carried out with the isolate and symptoms of leaf spot were found to appear after 7 days of inoculation. The pathogen was compared with 2 isolates of Colletotrichum capsici (CII and CIII) and one isolate of Colletotrichum gloeosporoides (CIV) from chilli. On the basis of morphological and cultural characteristics the pathogen was identified as $C$. capsici. For molecular identification random amplified polymorphic DNA (RAPD) primers and internal transcribed spacer (ITS2) primers were tested on the genome of Colletotrichum isolates from soybean and chilli plants and the data provided characteristic genetic evidence of $100 \%$ similarity within the CI isolate from soybean and C. capsici isolates from chilli (CII and CIII). To confirm the molecular identification of the pathogen species specific primers (CcapF/CcapR) were used and it was established that the pathogen is indeed $C$. capsici. Results of present investigation revealed the first report of $C$. capsici in soybean plant.
\end{abstract}

Keywords: Soybean - leaf-spot - Colletotrichum - RAPD - ITS.

[Cite as: Ghosh R, Bhadra S \& Bandyopadhyay M (2016) Morphological and molecular characterization of Colletotrichum capsici causing leafspot of soybean. Tropical Plant Research 3(3): 481-490]

\section{INTRODUCTION}

The genus Colletotrichum contains many morphologically similar taxa comprising endophytic, saprobic and plant pathogenic fungi (Photita et al. 2004, Damm et al. 2009). Anthracnose disease caused by the Colletotrichum species is a major problem worldwide. Among these species, C. gloeosporioides (Penz.) Penz. \& Sacc. and C. capsici (Syd.) E.J. Butler \& Bisby are most frequently cited as causal agents of anthracnose (Than et al. 2008, Gautam 2014, Ramdial \& Rampersad 2015). C. capsici also has been reported to have a wide putative host range associated with symptoms of foliar blight and leaf spot diseases (Shenoy et al. 2007). Leaf spot disease caused by Colletotrichum capsici is the most important economic constraint which hamper, turmeric (Curcuma longa L.) production in major turmeric growing regions of the India, and often results in high yield losses (Adhipathi 2013, Uma Devi 2008).

The occurrence of different virulent strains of Colletotrichum species has been well documented in India (Sharma et al. 2005, 2013). Numerous cases have been reported in which several Colletotrichum species or biotypes are associated with a single host (Peres et al. 2002) making their identification by morphological and physiological methods more difficult. The use of molecular marker techniques has improved the accuracy and speed of identification of Colletotrichum spp. (Cai et al. 2009). Among these molecular techniques, RAPD technique has been extensively used to investigate relationships among isolates of Colletotrichum spp. (Madhavan et al. 2010, Sangdee et al. 2011). Similarly nucleotide sequence information for the 5.8S rDNA gene and the internal transcribed spacer (ITS) region of ribosomal DNA (rDNA) have been used to design species specific primers of members of Colletotrichum for diagnostic purposes and for phylogenetic analysis (Thalhinhas et al. 2002).

Soybean is an important global crop that is grown in tropical, subtropical and temperate climate. Anthracnose is a major fungal disease of soybean which is caused by Colletotrichum capsici and several related 
species. Anthracnose of soybean can cause severe symptoms and yield loss in southern Taiwan. Strains of $C$. truncatum and C. gloeosporioides derived from diseased pods were noted as causal agents (Chen et al.1986). Purkayastha \& Banerjee (1990) reported anthracnose of soybean in India caused by C. dematium. Soybean foliage is also susceptible to a number of fungal and bacterial pathogens causing leaf spots and blights. Among leaf spot fungal diseases, brown spot disease caused by Septoria glycines and frogeye disease caused by Cercospora sojina are most frequently encountered (Hershman 2013).

In the present investigation an attempt was made to carry out morphological and molecular characterization of Colletotrichum isolate associated with leaf spot disease of soybean plants.

\section{MATERIALS AND METHODS}

Isolation and identification of pathogens from infected plants

Fungal isolate (CI) was collected from leaves of infected soybean plants grown in the field of experimental garden. The diseased leaf parts were cut at the advanced margin of lesions into small pieces $(5 \times 5 \mathrm{~mm})$ and then surface disinfected with $0.1 \% \mathrm{HgCl}_{2}$ for $1 \mathrm{~min}$, followed by rinsing with sterile distilled water two times. The pieces were then transferred to potato dextrose agar (PDA) medium and incubated at $30 \pm 2^{\circ} \mathrm{C}$ for $2-3$ days. Pure cultures of the fungi were obtained by single spore isolation method. The isolate was first identified to species by morphological observation under a compound microscope. Two other isolates of C. capsici (CII and CIII) and one isolate of $C$. gloeosporoides (CIV) from chilli were used for identification of C. capsici.

\section{Pathogenicity test}

In order to prove Koch's postulate pathogenicity test was carried out. One month old soybean plants were sprayed with spore suspension of $\mathrm{CI}\left(10^{6}\right.$ conidia/ml $)$ and covered with moist polythene bags for 48 hours under natural condition of light and temperature $\left(20-30^{\circ} \mathrm{C}\right)$. Disease intensity was measured after 5, 7, 10, 14, 21 days after inoculation following the method of Purkayastha \& Banerjee (1990). Disease symptom is necrotic spots (lesion) on the leaves of plant. Six leaves from each plant were selected randomly and the number and size of the lesions on each leaf were noted. On the basis of visual observation, the necrotic lesions were graded into small, medium and large groups and a value of $0.5,1$ and 2 were given to lesions denoting their diameter of 1,2 and more than $2 \mathrm{~mm}$ respectively. The number of spots in each group was multiplied by value assigned to it. The sum total values taken together for all leaves divided by the number of test plants.

\section{Cultural characters of Colletotrichum isolates}

Growth characteristics of fungal isolates were measured in potato dextrose agar (PDA) solid medium. The mycelial diameter and morphological nature of mycelia was recorded in solid medium. Shape and size of conidia of the fungal isolates were also observed.

\section{Fungal DNA extraction and RAPD analysis}

For DNA extraction, each isolate was grown in $100 \mathrm{ml}$ conical flasks, containing $30 \mathrm{ml}$ of potato dextrose broth, for 5 days at room temperature $\left(28 \pm 2^{\circ} \mathrm{C}\right)$. The mycelia were harvested by filtration and stored at $-20^{\circ} \mathrm{C}$ for 2-3 days. Freeze-dried mycelium $(0.5 \mathrm{~g})$ was ground to a fine powder and DNA was extracted using CTAB (hexa-decyltrimethylammonium bromide) method described by Bhadra \& Bandyopadhyay (2015). RAPD analysis was performed using 25 10-mer primers initially, among which 10 were chosen for final analysis due to high reproducibility of the banding pattern generated (Table 1). Amplification was performed in $25 \mu 1$ reaction volume consisting of $100 \mathrm{ng}$ template DNA, 100 pmole of primer, 10 milimole dNTPs (Applied Biosystems, Carlsbad, California, USA), $1.5 \mathrm{U}$ Taq DNA polymerase and $10 \mathrm{X}$ reaction buffer containing $15 \mathrm{mM} \mathrm{MgCl}$ (Merck Genei, Bangalore, India). PCR was performed using Veriti ${ }^{\circledR}$ 96-Well Thermal Cycler (Applied Biosystems, Carlsbad, California, USA) with an initial denaturation step for 5 minutes at $94^{\circ} \mathrm{C}$ followed by 40 cycles of 1 minute at $94^{\circ} \mathrm{C}, 1$ minute at $37^{\circ} \mathrm{C}$ and 2 minutes at $72^{\circ} \mathrm{C}$ with a final extension for 10 minutes at $72^{\circ} \mathrm{C} .1 .5 \%$ (W/V) agarose gel was used to analyse the PCR product. Size of the amplified fragments was determined using 100bp DNA ladder (Applied Biosystems, Carlsbad, California, USA). The gel was photographed using E-Gel® Imager (Applied Biosystems, Carlsbad, California, USA).

The amplified bands thus obtained were scored as present (1) or absent (0) for data analysis. Regardless of the intensity of the amplified band, each was treated as an independent entity. The $\mathrm{Rp}$ (resolving power) of each primer was calculated using the formula $\mathrm{Rp}=1-[2 *(0.5-\mathrm{p})]$ (where $\mathrm{p}$ is the proportion of taxa containing the band) (Prevost \& Wilkinson 1999). The scored binary matrix was then subjected to analysis using NTSYSpc 
software, version 2.02i (Rohlf 1999). Jaccard's similarity co-efficient was calculated using SIMQUAL program using the formula $\mathrm{N}_{\mathrm{AB}} /\left(\mathrm{N}_{\mathrm{AB}}+\mathrm{N}_{\mathrm{A}}+\mathrm{N}_{\mathrm{B}}\right)$ where $\mathrm{N}_{\mathrm{AB}}$ is the number of amplified fragments shared by samples, $\mathrm{N}_{\mathrm{A}}$ is the number of fragments in sample A, and, $\mathrm{N}_{\mathrm{B}}$ denotes those in sample B (Souframanien \& Gopalakrishna 2004).

Amplification and Sequencing of ITS1-5.8S-ITS2 of rDNA

The four Colletotrichum isolates were further characterized by nucleotide sequence analysis after amplification of the ITS1-5.8S-ITS2 regions using the universal primers ITS4 (5'-TCC TCC GCT TAT TGA TAT GC-3') and ITS5 (5'-GGA AGT AAA AGT CGT AAC AAG G-3') (White et al. 1990), and soybean isolate CI was used as positive control. PCR reactions were performed in reaction volumes of $50 \mu \mathrm{l}$ containing $25 \mathrm{ng}$ of genomic DNA, $1 \times$ PCR buffer (Merck Genei, Bangalore, India), $0.5 \mathrm{mM}$ of each dNTP (Applied Biosystems, Carlsbad, California, USA), $1 \mu \mathrm{M}$ primers, and 1U Taq polymerase (Merck Genei, Bangalore, India). DNA amplification was performed in a Veriti ${ }^{\circledR}$ 96-Well Thermal Cycler (Applied Biosystems, Carlsbad, California, USA), and the program consisted of an initial denaturing step at $95^{\circ} \mathrm{C}$ for $3 \mathrm{~min}$, followed by 25 cycles of $30 \mathrm{~s}$ at $95^{\circ} \mathrm{C}, 30 \mathrm{~s}$ at $54^{\circ} \mathrm{C}$, and $60 \mathrm{~s}$ at $72^{\circ} \mathrm{C}$; and a final extension step of $10 \mathrm{~min}$ at $72^{\circ} \mathrm{C}$. PCR products, approximately $600 \mathrm{bp}$, were separated by electrophoresis in $1.5 \%(\mathrm{~W} / \mathrm{V})$ agarose gels and visualized by ethidium bromide staining and were photographed using the gel documentation system. Specific bands were then cut off from gel and the amplified DNA was extracted using Silica Bead DNA Gel Extraction Kit (Thermo Fisher Scientific Inc., Waltham, MA USA).

DNA sequencing was performed with two primers (ITS4 and ITS5) in both directions to ensure that there was no misreading. PCR products were sequenced by ABI 3500 Genetic Analyzer (Applied Biosystems, Carlsbad, California, USA). Alignment and edition were carried out with the CAP3 Sequence Assembly Program (Huang \& Madan 1999) and visually corrected. Sequences were then compared using Mega 6.0 software program (Tamura et al. 2013).

\section{PCR using Species-Specific Primers}

Colletotrichum capsici specific primer pairs CcapF (5'-GTA GGC GTC CCC TAA AAA GG-3') and CcapR (5'-CCC AAT GCG AGA CGA AAT G-3') previously reported by Torres-Calzada et al. (2011) were used for rDNA amplification of all the samples. Amplification reactions were performed using protocol reported earlier. PCR products were visualized by electrophoresis in $1.5 \%$ (W/V) agarose gels, stained with ethidium bromide and documented using gel documentation system.

\section{RESULTS AND DISCUSSION}

Identification of pathogen

Pathogen associated with leaf spot disease of soybean was identified as C. capsici on the basis of morphological characteristics.

\section{Pathogenicity test}

Healthy soybean plants were inoculated after one month of sowing and disease index was noted after 5, 7, 10, 14 and 21 days of inoculation. Symptoms were found to appear 7 days of inoculation and disease intensity was found to increase with the incubation period. Disease symptom was noted as necrotic spots (lesion) on the leaves of the plant. The results are presented in the table 1 and figures $1 \mathrm{~A} \& \mathrm{~B}$.

Table 1. Pathogenicity test of Colletotrichum capsici (CI) on healthy soybean cultivar.

\begin{tabular}{ll}
\hline Incubation period (days) $^{\mathrm{a}}$ & Disease index / plant \\
\hline 5 & 0 \\
7 & 3.5 \\
10 & 5.75 \\
14 & 7.25 \\
21 & 8 \\
\hline Note: ${ }^{\mathrm{b}}$ - Days after inoculation; ${ }^{\mathrm{b}}$ - Average of 4 plants. Age of plant at the \\
time of inoculation: 1 month; Inoculation potential: $10^{6}$ conidia/ml
\end{tabular}

\section{Cultural characteristics}

The mycelial growth of Colletotrichum isolates in solid PDA medium was measured after 12 days of incubation. The CI, CII and CIII isolates showed dense white to greyish brown mycelia with ring like zonations 
in solid oat meal medium (Fig. 1C). C. gloeosporoides (CIV) produced pinkish white colony with cylindrical conidia (Table 2).

Table 2. Morphological and cultural characters of strains of Colletotrichum capsici.

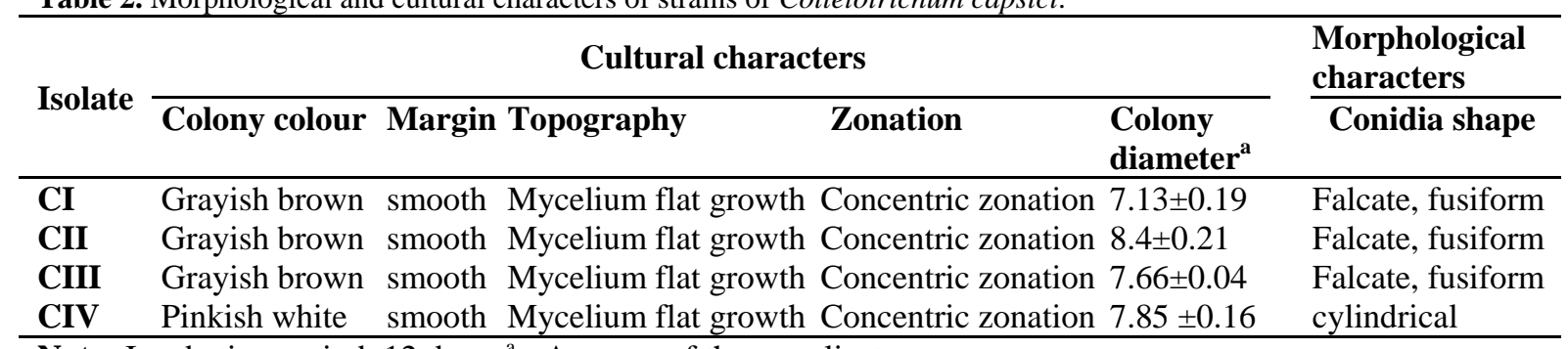

Note: Incubation period: 12 days. ${ }^{a}$ - Average of three replicates.
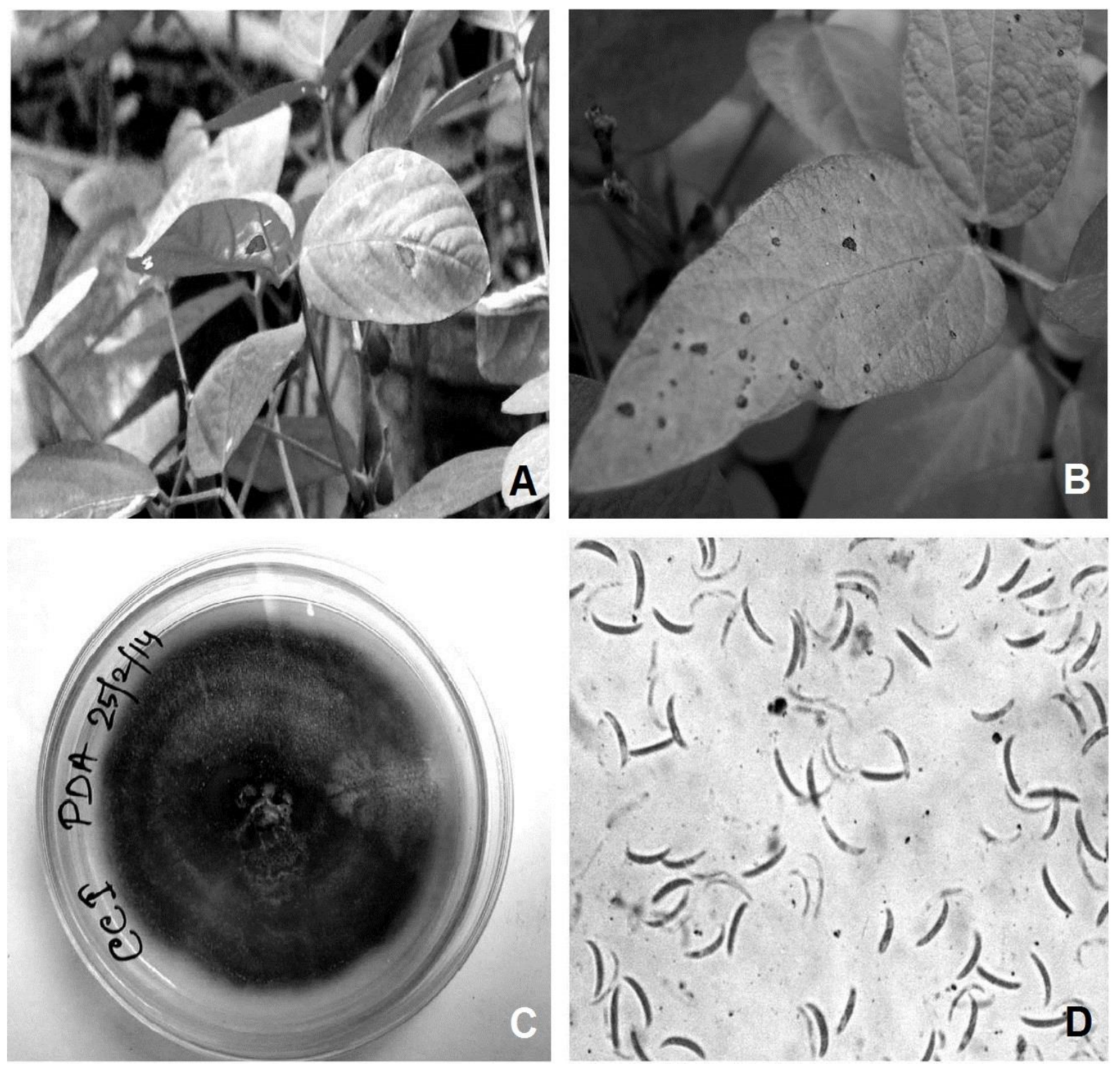

Figure 1. Symptoms of leaf spot disease on infected leaves of soybean and morphological and cultural characters of the pathogen.

\section{Morphological characters}

The conidia of Colletotrichum isolates from soybean and chilli (CI, CII and CIII) is falcate, fusiform with acute apices. (Fig. 1D) The size ranges from 19.65-21.00 $\mu \mathrm{m}$ in length and 3.0-3.5 $\mu \mathrm{m}$ in breadth. In $C$. gloeosporiodes (CIV) conidia are hyaline, one celled, cylindrical. The size ranges from $8-12 \mu \mathrm{m}$ in length and 4-6 $\mu \mathrm{m}$ in width. 
Molecular identification of the pathogen

i. RAPD-PCR analysis

25 RAPD primers were tested on the genome of CI, CII, CIII and CIV. The generated DNA fingerprints were evaluated for assessing genetic similarity among the four isolates. Data generated by 10 primers were analyzed as they reliably and reproducibly detected polymorphism among the selected isolates (Table 3). Figure 2 shows typical profile and polymorphic bands generated after amplification with the primers.

Table 3. List of primers used, their sequences, and amplified products generated.

\begin{tabular}{lllllll}
\hline Primer & \multirow{2}{*}{ Sequence of primers } & $\begin{array}{l}\text { Total number } \\
\text { of bands }\end{array}$ & $\begin{array}{l}\text { Number of } \\
\text { polymorphic bands }\end{array}$ & $\begin{array}{l}\text { Number of } \\
\text { monomorphic bands polymorphism }\end{array}$ & $\begin{array}{l}\text { Percentage } \\
\text { power (Rp) }\end{array}$ \\
\hline OPA 04 & 5'-AATCGGGCTG-3' & 35 & 31 & 4 & 88.6 & 35.5 \\
OPA 11 & 5'-CAATCGCCGT-3' & 29 & 24 & 5 & 82.8 & 33 \\
OPB 01 & 5'-GTTTCGCTCC-3' & 16 & 14 & 2 & 87.5 & 16.5 \\
OPB 07 & 5'-GGTGACGCAG-3' & 27 & 23 & 4 & 85.2 & 31.5 \\
OPC 09 & 5'-CTCACCGTCC-3' & 22 & 19 & 3 & 86.4 & 23.5 \\
OPD 04 & 5'-TCTGGTGAGG-3' & 15 & 14 & 1 & 93.3 & 15 \\
OPE 03 & 5'-CCAGATGCAC-3' & 37 & 36 & 1 & 97.3 & 35.5 \\
OPG 08 & 5'-TCACGTCCAC-3' & 26 & 23 & 3 & 88.5 & 29.5 \\
OPK 17 & 5'-CCCAGCTGTG-3' & 32 & 30 & 2 & 93.8 & 35.5 \\
OPL 03 & 5'-CCAGCAGCTT-3' & 37 & 36 & 1 & 97.3 & 40 \\
\hline
\end{tabular}
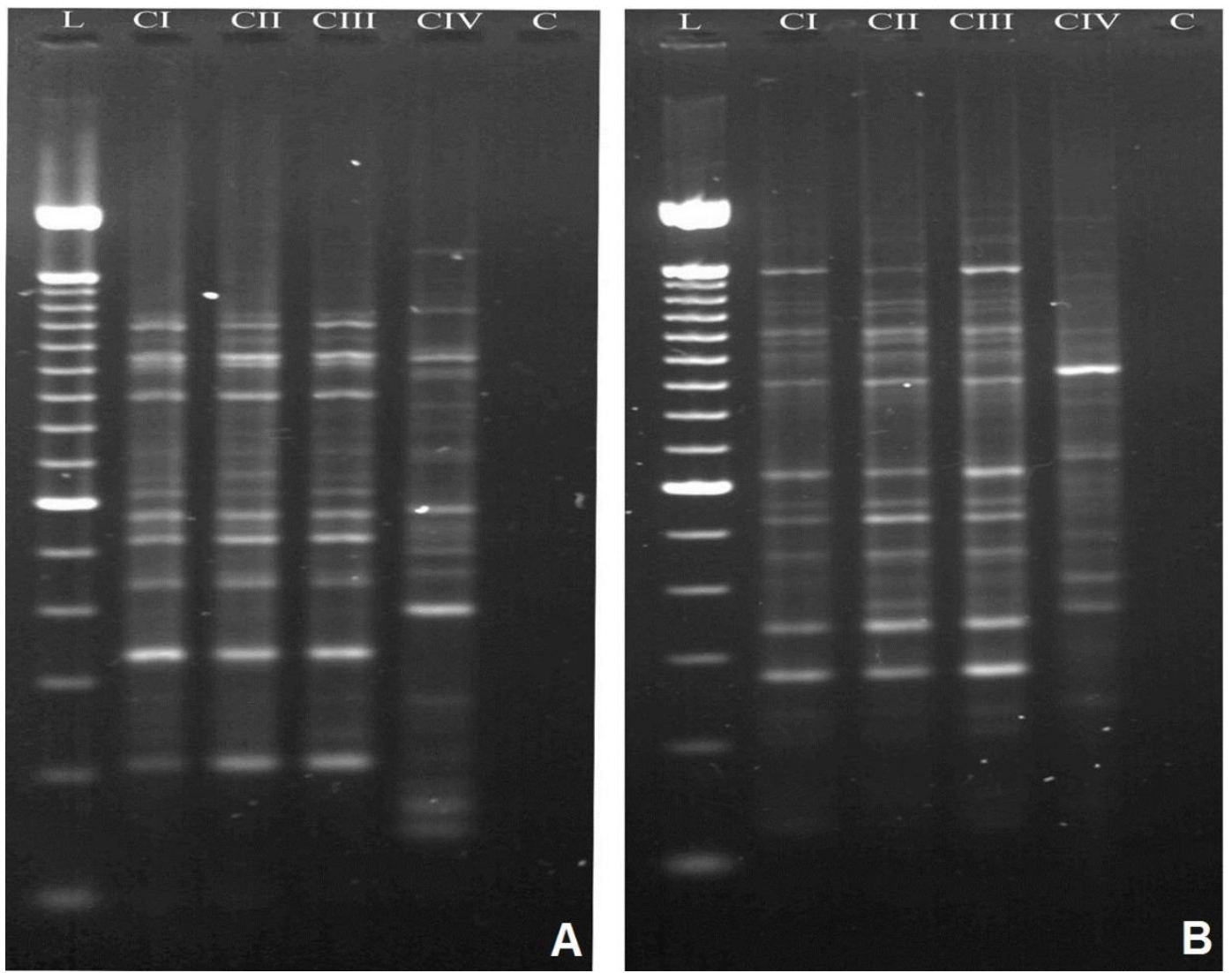

Figure 2. RAPD amplification patterns of four Colletotrichum isolates using the primers OPC09 and OPA11. L: Ladder; CI, CII, CIII \& CIV: Colletotrichum isolates; C: negative control.

The 10 RAPD primers produced a total of 276 amplified fragments with 250 polymorphic and 26 monomorphic bands. The average polymorphism of these primers varied from $82.8 \%$ to $97.30 \%$ with an average of $90.05 \%$. The resolving power ( $\mathrm{Rp}$ ) of the primers varied from 15 to 40 . Table 3 summarizes the above data.

The dendrogram generated from the RAPD data using Jaccard's similarity coefficient showed a variation from 0.10 to 1.00 among the four isolates. While the three Colletotrichum isolates (CI, CII and CIII) separated out in a single cluster showing 0.85 similarity coefficient among them, C. gloeosporoides (CIV) showed similarity coefficient of 0.10 with them. Based on the high similarity value of 1.0 between CI and CII it may be assumed that both of them belong to the same species (Fig. 3). 


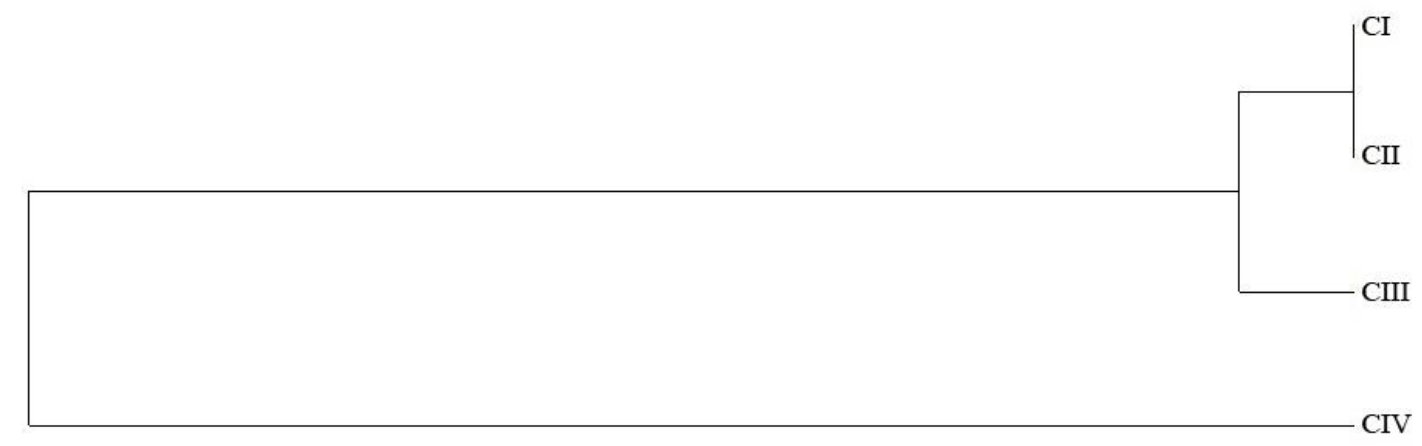

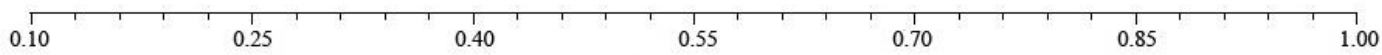

Figure 3. Dendogram generated using Jaccard's similarity distance obtained from RAPD primers. CI, CII, CIII \& CIV: Colletotrichum isolates.

ii. Amplification and Sequencing of ITS1-5.8S-ITS2 of rDNA

To further confirm the result obtained using RAPD marker-based study, PCR amplification of the ITS region of all the studied samples were also done using universal primers ITS4 and ITS5. A single band of 620 bp was obtained in all cases (Fig. 4). No nonspecific banding was found. The amplified fragments were, thus, purified and sequenced.

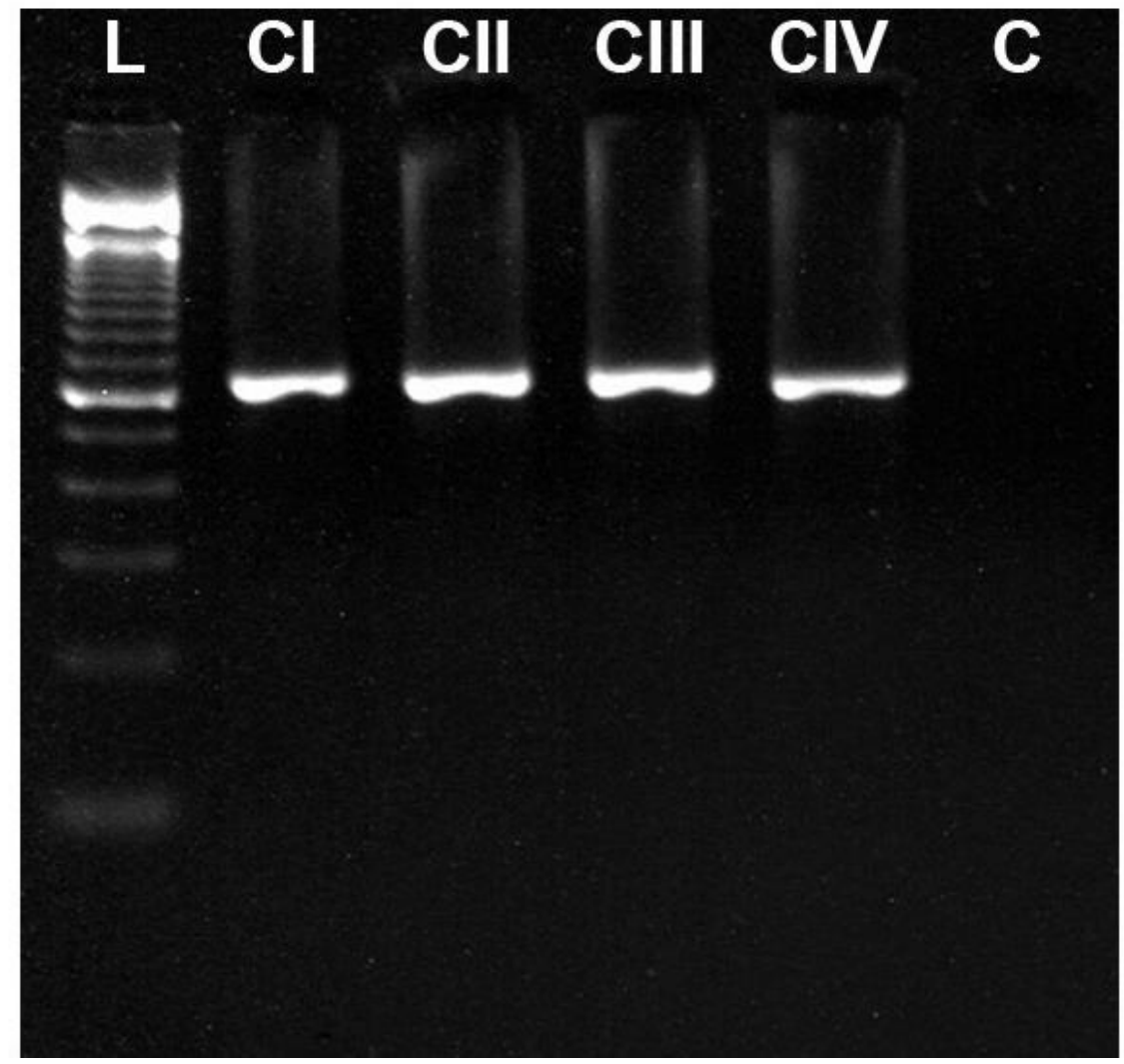

Figure 4. Products of PCR amplification of ITS region using primer set ITS 4and ITS 5. Lane L: Marker DNA ; CI,CII,CIII \& CIV: Colletotrichum isolates; C: negative control.

The sequence data, thus obtained, were compared using Mega 6.06 software. The sequence analysis of the ITS region revealed $100 \%$ sequence similarity within the three isolates namely CI, CII and CIII. The ITS2 sequence of $C$. gloeosporoides (CIV), on the other hand, revealed significant difference with other three isolates (Fig. 5). The sequences were also used to generate a dendrogram revealing phylogenetic relationship among the studied taxa using UPGMA method (Fig. 6). 


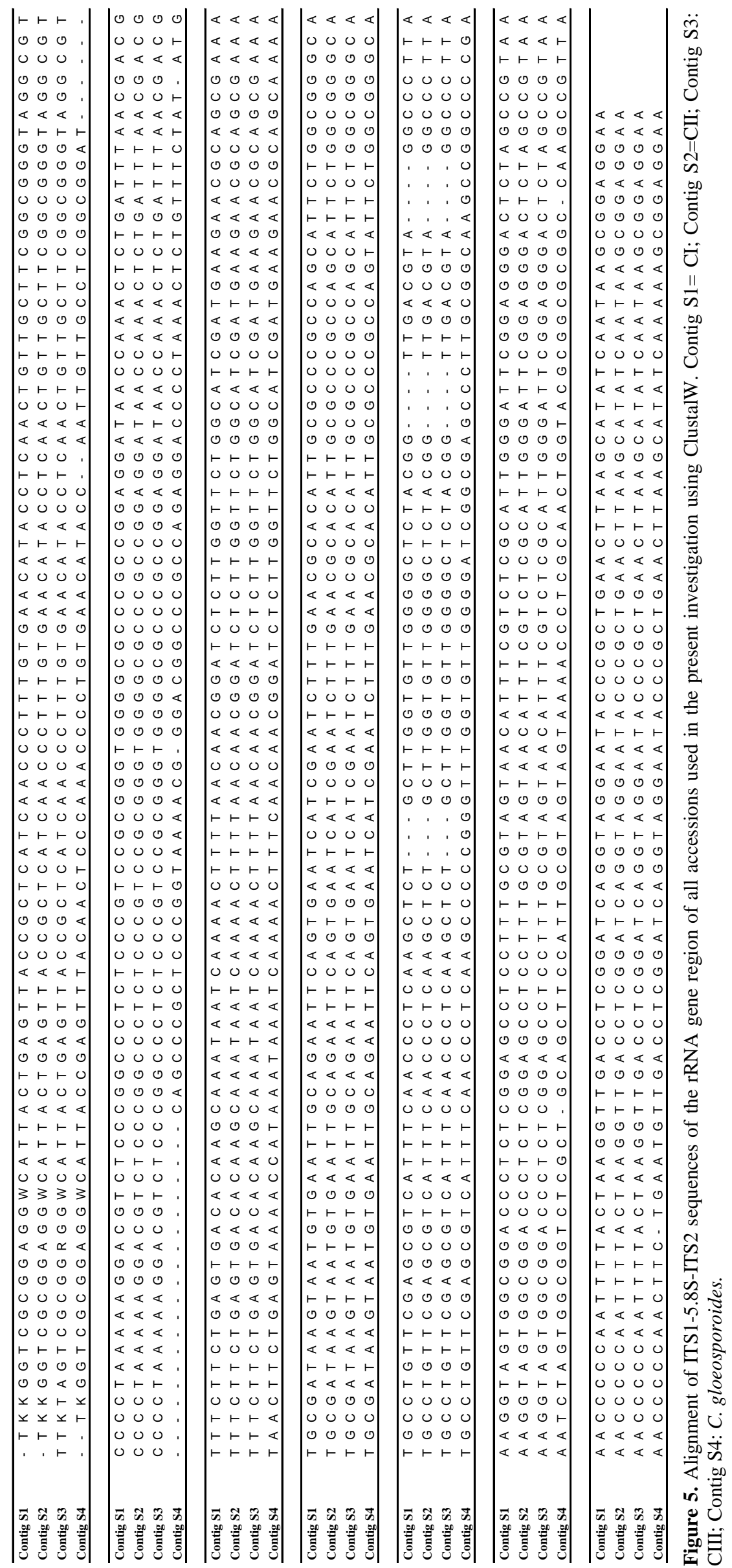




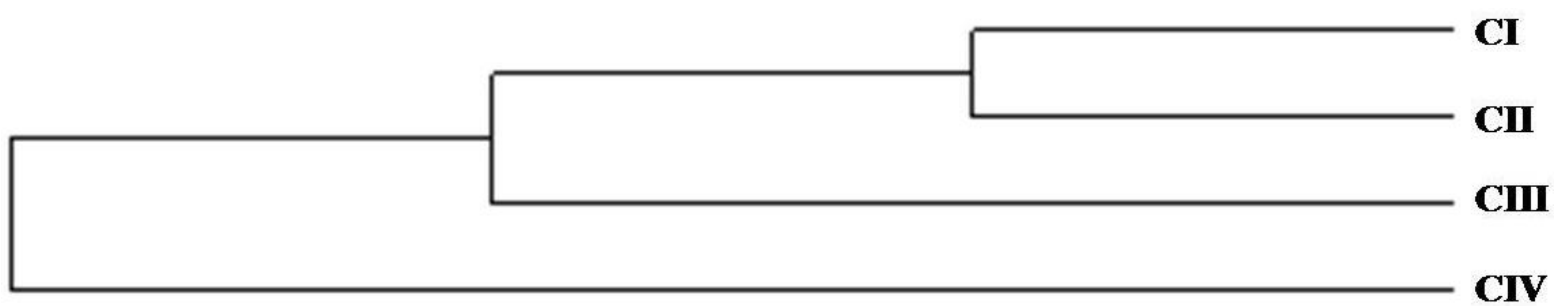

Figure 6. Dendogram generated using the UPGMA method obtained from ITS sequences. CI, CII, CIII \& CIV: Colletotrichum isolates.

\section{iii. PCR using Species-Specific Primers}

When the primer pair CcapF/CcapR were used to amplify the genomic DNA in the present study, the two chilli isolates of C. capsici (CII and CIII) and the CI isolate from soybean tested positive with a single amplified fragment in each taxa. The size of this fragment was $394 \mathrm{bp}$ in all of the $C$. capsici tested. The primers, however, used failed to amplify genomic DNA of C. gloeosporoides (Fig. 7).

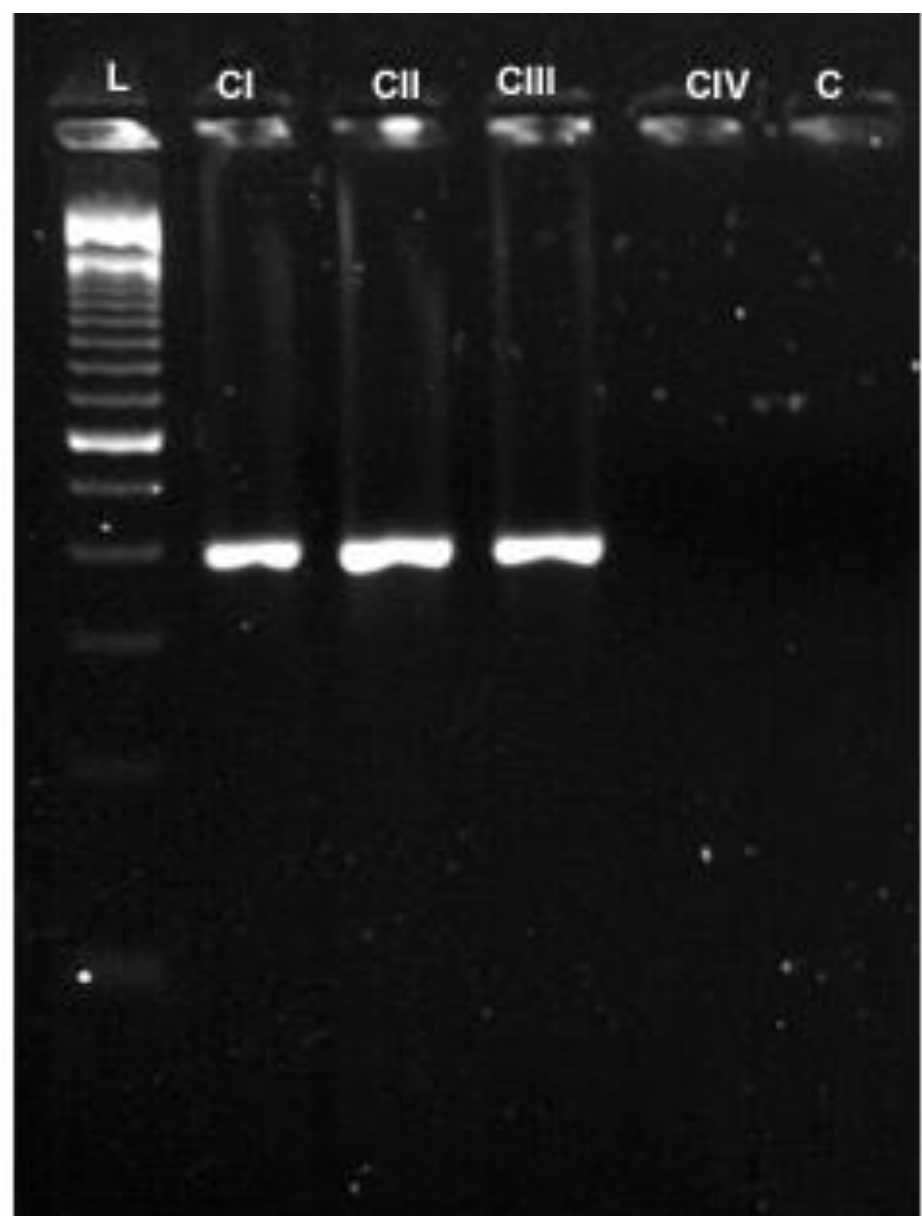

Figure 7. Products of PCR amplification using C.capsici specific primer pairs Ccap F / Ccap R. Lane L: Marker DNA; CI, CII, CIII \& CIV: Colletotrichum isolates; C: negative control.

\section{DISCUSSION}

In the present investigation results of pathogenicity test indicated that Colletotrichum sp. (CI isolate) can establish leaf spot disease in susceptible soybean cultivar. Traditional identification and characterization of Colletotrichum species relies primarily on difference in morphological features such as colony, colour, size and shape of conidia and appressoria. In this study morphological characterization of Colletotrichum isolates from chilli and soybean plants were done. Results revealed that CI, CII and CIII isolates showed similar characteristics, whereas CIV is morphologically different from the other 3 isolates. This result is in agreement with a previous study by Sandgee et al. (2011) who found a morphometric overlap of conidial size among Colletotrichum species. Thangamani et al. (2011) performed morphological and physiological characterization of Colletotrichum musae, the causal organism of banana anthracnose. However morphological characterizations www.tropicalplantresearch.com 
are not always adequate for reliable differentiation among species of Colletotrichum. Thus molecular methods have been employed successfully to differentiate between populations of Colletotrichum from many hosts. In the present investigation, RAPD primers were tested on genome of four Colletotrichum isolates. Analysis of data generated using 10 RAPD primers exhibited polymorphism varying from $82.76 \%$ to $97.30 \%$ with an average of $90.05 \%$. Cluster analysis using Jaccard's coefficient clearly separated the isolates of chilli and soybean from C. gloeosporioides. RAPD analysis was also performed by Ratancherdchai et al. (2007) on 18 isolates belonging 2 species, $C$. gloeosporiodes and $C$. capsici isolated from three varieties of chilli, i.e. chilli pepper (Capsicum annum), long cayenne pepper (C. annuum var. acuminatum) and Birds eye chilli ( $C$. frutescens). Their study showed that a clear difference could be established between $C$. gloeosporiodes and $C$. capsici. The three $C$. capsici isolates analysed in the present study show similarity of $0.85-1.00$ among themselves. The existence of molecular variability among isolates of $C$. capsici that differed in virulence was earlier established by Srinivasan et al. (2010) using RAPD markers. The result of RAPD in the present investigation was further confirmed by sequence analysis of the ITS region which revealed $100 \%$ sequence similarity between the two C. capsici isolates of chilli and CI isolate of soybean. C. gloeosporoides, on the other hand, revealed significant sequence difference with $C$. capsici isolates CI. Freeman (2008) used sequence analysis of ITS region to establish similarity between Colletotrichum acutatum isolates from almond and strawberry. Shi et al. (2008) had used ITS universal primer pair ITS1-F/ITS4 to characterize Colletotrichum acutatum and C. gloeosporioides isolates from flowering dogwood (Cornus florida). Katoch et al. (2016) carried out Metageographic population analysis of Colletotrichum truncatum associated with chili fruit rot and other hosts using ITS region nucleotide sequences. Molecular characterization of the soybean isolate was finally established by using species specific primer which revealed that this isolate and two other $C$. capsici isolates tested positive with a single amplified fragment in each taxa. C. gloeosporoides, however, failed to produce any amplified DNA fragment using these primers. The results of molecular characterization and morphological identification thus established that the CI isolate from soybean is $C$. capsici. $C$. capsici was not reported in soybean till date. Results of present investigation revealed the first report of $C$. capsici in soybean plant.

\section{ACKNOWLEDGEMENT}

Scientific assistance received from UGC, Govt. of India is gratefully acknowledged.

\section{REFERENCES}

Adhipathi P, Nakkeeran S \& Chandrasekaran A (2013) Morphological characterization and molecular phylogeny of Colletotrichum capsici causing leaf spot disease of turmeric. The Bioscan 8: 331-337.

Bhadra S \& Bandyopadhyay M (2015) A fast and reliable method for DNA extraction from different plant parts of Zingiberaceae. Journal of the Botanical Society of Bengal 69(2): 91-98.

Cai L, Hyde KD, Taylor PWJ, Weir BS, Waller JM, Abang MM, Zhang JZ, Yang YL, Phoulivong S, Liu ZY, Prihastuti H, Shivas RG, McKenzie EHC \& Johnston PR (2009) A polyphasic approach for studying Colletotrichum. Fungal Diversity 39: 183-204.

Chen LS, Chu C, Liu C, Chen RS \& Tsay JG (2006) PCR-based detection and differentiation of Anthracnose pathogens, Colletotrichum gloeosporioides and C. truncatum, from vegetable soybean in Taiwan. Journal of Phytopathology 154: 654-662.

Damm U, Woudenberg JHC, Cannon PF \& Crous PW (2009) Colletotrichum species with curved conidia from herbaceous hosts. Fungal Diversity 39: 45-87.

Freeman S (2008) Management, Survival Strategies, and Host Range of Colletotrichum acutatum on Strawberry. Hortscience 43: 66-68.

Gautam AK (2014) The genera Colletotrichum: an incitant of numerous new plant diseases in India. Journal on New Biological Reports 3(1): 9-21.

Hershman DE (2003) Soybean Foliar Spots and Blights. Available from: http://www.ca.uky.edu/agcollege/plant pathology/ext_files/ PPFShtml /ppfsags19.pdf (accessed: 10 Feb. 2016).

Huang X \& Madan A (1999) CAP3: A DNA sequence assembly program. Genome Research 9: 868-877.

Katoch A, Prabhakar CS \& Sharma PN (2016) Metageographic population analysis of Colletotrichum truncatum associated with chili fruit rot and other hosts using ITS region nucleotide sequences. Journal of Plant Biochemistry and Biotechnology 25: 64-72. 
Madhavan S, Paranidharan V \& Velazhahan R (2010) RAPD and virulence analyses of Colletotrichum capsici isolates from chilli (Capsicum annuum). Plant Diseases and Protection 117: 253-257.

Peres NR, Kuramae EE, Dias CM \& De'souza N (2002) Identification and characterization of Colletotrichum spp. affecting fruit after harvest in Brazil. Journal of Phytopathology 150: 128-134.

Photita W, Taylor PWJ, Ford R, Hyde KD \& Lumyong S (2005) Morphological and molecular characterization of Colletotrichum species from herbaceous plants in Thailand. Fungal Diversity 18: 117-133.

Prevost A \& Wilkinson MJ (1999) A new system of comparing PCR primers applied to ISSR fingerprinting of potato cultivars. Theoretical and Applied Genetics 98: 107-112.

Purkayastha RP \& Banerjee R (1990) Immunoserological studies of cloxacillin-induced resistance of soybean against anthracnose. Zeitschrift für Pflanzenkrankheiten und Pflanzenschutz 97: 349-359.

Ramdial H \& Rampersad SN (2015) Characterization of Colletotrichum spp. causing anthracnose of bell pepper (Capsicum annuum L.) in Trinidad. Phytoparasitica 43: 37-49.

Ratanacherdchai K, Wang HK, Lin FC \& Soytong K (2007) RAPD analysis of Colletotrichum species causing chilli anthracnose disease in Thailand. Journal of Agricultural Technology 3: 211-219.

Rohlf FJ (1999) NTSYS-pc Numerical Taxonomy and Multivariate Analysis System. Version 2.02i. Exeter Software, Setauket, New York, US.

Sangdee A, Sachan S \& Khankhum S (2011) Morphological, pathological and molecular variability of Colletotrichum capsici causing anthracnose of chilli in the North-east of Thailand. African Journal of Microbiology Research 5: 4368-4372.

Sharma G, Pinnaka AK \& Shenoy BD (2013) ITS-based diversity of Colletotrichum from India. Current Research in Environmental \& Applied Mycology 3: 194-220.

Sharma PN, Kaur M, Sharma OP, Sharma P \& Pathania A (2005) Morphological, pathological and molecular variability in Colletotrichum capsici, the cause of fruit rot of chillies in the subtropical region of northwestern India. Journal of Phytopathology 153: 232-237.

Shenoy BD, Jeewon R, Lam WH, Bhat DJ, Than PP, Taylor PWJ \& Hyde KD (2007) Morpho-molecular characterisation and epitypification of Colletotrichum capsici (Glomerallaceae, Sordariomycetes) the causative agent of anthracnose in chilli. Fungal Diversity 27: 197-211.

Shi ABC, Kantartzi SK, Mmbaga MT, Chen P, Mrema F \& Nnodu E (2008) PCR-based markers for detection of Colletotrichum acutatum and C. gloeosporioides in flowering dogwood (Cornus florida). Australasian Plant Pathology 37: 65-68.

Souframanien J \& Gopalakrishna T (2004) A comparative analysis of genetic diversity in blackgram genotypes using RAPD and ISSR markers. Theoretical and Applied Genetics 109: 1687-1693.

Srinivasan M, Vaikuntavasan P \& Rethinasamy V (2010) RAPD and virulence analyses of Colletotrichum capsici isolates from chilli (Capsicum annuum). Journal of Plant Diseases and Protection 117: 253-257.

Talhinhas, P, Sreenivasaprasad S, Neves-Martins J \& Oliveira H (2002) Genetic and morphological characterization of Colletotrichum acutatum causing anthracnose of lupins. Phytopathology 92: 986-996.

Tamura K, Stecher G, Peterson D, Filipski A \& Kumar S (2013) MEGA6: Molecular Evolutionary Genetics Analysis version 6.0. Molecular Biology and Evolution 30: 2725-2729.

Than PP, Prihastuti H, Phoulivong S, Taylor PWJ \& Hyde KD (2008) Chilli anthracnose disease caused by Colletotrichum species. Journal of Zhejiang University Science Biology 9: 764-778.

Thangamani PR, Kuppusamy P, Peeran MF, Gandhi K \& Thiruvendam R (2011) Morphological and physiological characterization of Colletotrichum musae the causal organism of banana anthracnose. World Journal of Agricultural Sciences 7: 743-754.

Torres-Calzada C, Tapia-Tussell R, Quijano-Ramayo A, Martin-Mex R, Rojas-Herrera R, Higuera-Ciapara I \& Perez-Brito D (2011) A Species-Specific Polymerase Chain Reaction Assay for Rapid and Sensitive Detection of Colletotrichum capsici. Molecular Biotechnology 49: 48-55.

Uma Devi G (2008) Efficacy of fungicides against Colletotrichum leaf spot of turmeric. Indian Journal of Plant Protection 36: 112-113.

White TJ, Bruns T, Lee S \& Taylor J (1990) Amplification and direct sequencing of fungal ribosomal RNA genes for phylogenetics. In: Innis MA, Gelfand DH \& Sninsky JJ (eds) PCR Protocols: a guide to methods and applications. Academic Press, San Diego, CA, pp. 315-322. 